\title{
Smoothened Antagonist LEQ506
}

National Cancer Institute

\section{Source}

National Cancer Institute. Smoothened Antagonist LEQ506. NCI Thesaurus. Code C91089.

An orally bioavailable small-molecule Smoothened (Smo) antagonist with potential antineoplastic activity. Smoothened antagonist LEQ506 selectively binds to the Hedgehog ( $\mathrm{Hh}$ )-ligand cell surface receptor Smo, which may result in the suppression of the Hh signaling pathway, thereby inhibiting tumor cell growth. The Hh signaling pathway plays an important role in cellular growth, differentiation and repair. Dysregulated activation of Hh pathway signaling and uncontrolled cellular proliferation, as is observed in a variety of cancers, may be associated with mutations in the Hh-ligand cell surface receptor Smo. 